\title{
PENGARUH PENDEKATAN SAINTIFIK DALAM PROSES BELAJAR MENGAJAR SISWA KELAS VIII MATERI LINGKARAN
}

\author{
Maryani ${ }^{1}$, Herlina Effendi ${ }^{2}$, Henky Sabantaro ${ }^{3}$ \\ Mahasiswa Tadris Matematika, Fakultas Tarbiyah dan Tadris (IAIN) Bengkulu \\ email : ${ }^{1}$ mariani030699@gmail.com \\ ${ }^{2}$ Herlinaeffendi449@gmail.com \\ 3hengkybk1871@gmail.com
}

\begin{abstract}
Abstrak
Penelitian ini bertujuan untuk mengetahui hasil belajar siswa yang diajar menggunakan metode pendekatan saintifik secara berkelompok dan tidak berkelompok. Penelitian ini adalah penelitian kuantitatif. Populasi penelitian ini siswa kelas VIII SMP Negeri 03 Kota Bengkulu. Pengambilan sampel pada penelitian ini dilakukan secara purposive sampling karena tidak semua sampel memiliki kriteria yang sesuai dengan fenomena yang diteliti. Dua kelas yang dipilih yaitu Kelas VIII A dan VIII B yang masing-masing berisikan 8 siswa. Setiap siswa mendapatkan materi berdasarkan kurikulum yang sama, kedua sampel dalam satu kelas yang sama, guru menggunakan metode yang sama, karateristik pembelajaran serta kemampuan awal siswa sebanding. Pengumpulan data yang digunakan dalam penelitian ini menggunakan observasi dan uji Test Soal. Berdasarkan hasil data diatas yang menggunakan uji non parametris Mann Whitney Test didapatkan bahwa hasil belajar matematika pada kelas A lebih besar dengan angka mean Rank 8,63 Sedangkan pada kelas B dengan angka mean Rank 8,38. Berdasarkan output Test statistics diketahui bahwa nilai Asymp Sig.(2.talled) sebesar 0,916 $<0,05$ Hipotesis diterima, maka dapat dikatakan bahwa adanya perbedaan dari hasil yang signifikan antara kelas A dan kelas B dengan pengaruh pembelajaran kelas eksperimen dan kelas control.
\end{abstract}

Kata Kunci : Pendekatan Saintifik, belajar,lingkaran

\begin{abstract}
This study aims to determine students' learning outcomes who are taught using the scientific approach method in groups and not in groups. This research is quantitative. The study population was grade VIII students of SMP Negeri 03 Bengkulu City. In this study, sampling was carried out by purposive sampling because not all samples have criteria that match the phenomenon under study. The two classes chosen were Class VIII A and VIII B, each of which contained eight students. Each student gets material based on the same curriculum, the two samples in the same class, the teacher uses the same method, the characteristics of learning, and the students' initial abilities. Collecting data used in this study using observation and test questions. Based on the results of the above data using the non-parametric Mann Whitney Test, it was found that the results of learning mathematics in class $A$ were greater with a mean Rank of 8.63, while in class B with a mean Rank of 8.38. Based on the output test statistics, it is known that the Asymp Sig. (2.talled) value is $0.916<0.05$. The hypothesis is accepted. It can be said that there is a significant difference in results between class $A$ and class $B$ with the effect of learning in the experimental class and the control class.
\end{abstract}

Keywords: Scientific Approach, study, Circle

\section{PENDAHULUAN}

Pendidikan memiliki peranan penting dalam mempersiapkan sumber daya manusia yang berkualitas sehingga mampu bersaing dalam perkembangan ilmu pengetahuan dan teknologi (IPTEK) yang canggih pada sekarang ini. Kurikulum adalah suatu bagian dari salah satu faktor yang mempengaruhi sistem pendidikan nasional . kurikulum harus dapat mengikuti dinamika yang terdapat pada masyarakat dan harus bisa menjawab kebutuhan masyarakat dalam menghadapi persoalan yang dihadapi. Pendidikan dapat dikatakan sebagai pondasi utama dalam menentukan perubahan sosial. Perubahan sosial mengarahkan kemajuan dan kesejahteraan 
hidup yang berkualitas. Didalam Undang-Undang Republik Indonesia nomor 20 pasal 1 Tahun 2003 tentang system pendidikan nasional (Sisi diknas) bahwa Pendidikan dapat diartikan sebagai usaha sadar dan terencana untuk mewujudkan suasana dalam proses pembelajaraan. yang dilakukan siswa belajar secara aktif yang Dapat mengembangkan potensi dirinya untuk memiliki kekuatan spiritual keagamaan, pengendalian diri, kepribadian, kecerdasan, akhlak mulia serta keterampilan yang diperlukan dirinya masyarakat bangsa dan negara serliana (dalam hanafian \& cucu suhana 2017).

Proses belajar mengajar atau pembelajaran dapat diartikan sebagai suatu kegiatan melaksanakan kurikulum dalam lembaga pendidikan supaya siswa dapat mencapai tujuan yang telah ditetapkan. pendidikan bertujuan untuk dapat mengantarkan para siswa menuju perubahan tingkah laku baik dari segi intelektual, moral maupun sosial budaya. Dengan pendidikan diharapkan supaya siswa dapat mencapai tujuan yang telah ditetapkan (Lestari,2015). Dengan melakukan proses belajar siswa dapat mencapai suatu tujuan hingga tercapai. Proses belajar mengajar atau pembelajaran dapat diartikan sebagai suatu kegiatan melaksanakan kurikulum dalam lembaga pendidikan supaya siswa dapat mencapai tujuan yang telah ditetapkan. pada saat proses berlangsung siswa dianjurakan agar dapat mengolah informasi dengan pengetahuan yang bermanfaat dan juga menjadi landasan belajar yang berkelanjutan, serta perubahan yang lebih baik untuk mencapai tujuan dengan terciptanya proses belajar yang efektif dan efesian.

Pembelajaran sebagai proses belajar yang dibangun oleh guru secara langsung untuk mengembangkan suatu kreativitas berpikir yang dapat meningkatkan kemampuan berfikir siswa serta dapat menggunakan kemampuan dalam mengkontruksi pengetahuan dari upaya meningkatkan penghargaan yang baik pada materi pelajaran. Pelajaran Matematika adalah mata pelajaran yang dipelajari mulai dari sekolah dasar (SD) sampai dengan perguruan tinggi. Matematika juga merupakan salah satu disiplin ilmu yang dapat meningkatkan kemampuan siswa dalam berpikir dan berargumentasi, berkontribusi. Untuk melakukan penyelesaian suatu masalah dalam kehidupan sehari-hari dalam dunia kerja serta dapat memberikan dukungan dalam perkembangan IPTEK. Salah satu pendidikan yang mampu mengembangkan potensi siswa ialah pendidikan matematika, matematika biasanya dianggap sulit dan menakutkan bagi siswa untuk dipelajari. Ruseffendi (2006:156) menyatakan dalam pelajaran matematika siswa harus menyelesaikan soal-soal Matematika, menghafal rumus-rumus Matematika dan memahami konsep-konsep yang ada dalam pelajaran tersebut, tetapi masih banyak siswa yang belum memahami tentang cara belajar Matematika sehingga siswa menganggap bahwa mempelajari Matematika adalah hal yang sulit. Untuk mencapai hasil tersebut dengan baik siswa dianjurkan agar dapat melakukan ativitas belajar lebih baik. Purwanto (2002:85) mengemukakan bahwa belajar merupakan suatu yang tidak dapat dilihat secara langsung maksudnya belajar hanya tumbuh dari pribadi diri seseorang karena proses itu terjadi saat diri seseorang yang mempunyai keinginan untuk mengubah suatu perubahan pada dirinya. Sukses untuk belajar tergantung dengan faktor yang dipengaruhi oleh waktu, belajar akan efektif apabila siswa benar-benar dapat memanfaatkanya.

Berdasarkan observasi yang saya peroleh di SMP Negeri 03 Kota Bengkulu dibulan Januari 2020 bahwa kurikulum K13 sudah berjalan disekolah dengan menggunakan metode pendekatan saintifik tetapi pada saat proses pembelajaran berlangsung metode tersebut jarang digunakan oleh guru karena pada saat menggunakan metode saintifik proses pembelajaran hanya sekedar menghabisi waktu saja sedangkan pada saat pembelajaran berlangsung kondisi siswa-siswa nya masih kurang kondusif. Pada saat proses belajar mengajar berlangsung banyak siswa-siswa yang masih cenderung. Pada saat guru akan mengakhiri mata pelajaran biasanya guru meminta siswa-siswanya untuk menyimpulkan materi diakhir pelajaran dihari itu, tetapi ketika Guru menunjuk siswa tersebut untuk menyimpulkan materi yang telah dibahas, siswa hanya berpurapura berpikir dan siswa tersebut hanya diam karena tidak paham pada saat Guru sedang menjelaskan / berdiskusi. Ketika Guru menggunakan metode saintifik dampak bagi siswa pada saat berdiskusi kelompok atau kerja kelompok anak tersebut hanya sibuk sendiri, akibatnya apa 
yang telah Guru sampaikan atau yang telah dijelaskan dengan materi yang sedang berlangsung siswa tersebut tidak mengerti dengan materi yang telah disampaikan dihari itu karena pada saat guru sedang menjelaskan materi siswa tersebut sibuk dengan teman kelompoknya, hal tersebut berakibat bahwa pada saat pembelajaran menggunakan pendekatan saintifik siswa tersebut tidak kondusif..

Pendekatan scientifik adalah pembelajaran yang menggunakan kaidah-kaidah keilmuan. Pendekatan scientifik atau metode ilmiah pada umumnya memuat serangkaian aktifitas, pengumpulan data melalui observasi, menanya, eksperimen, mengolah informasi atau data, kemudian mengkomunikasikan. Majid (2014:193) menyatakan pendekatan saintifik adalah pendekatan Untuk membangun bentuk sikap yang religi, sosial, pengetahuan dan keterampilan pada siswa dalam pelajaran siswa dijadikan dalam subjek pembelajaran, tidak lagi dijadikan sebagai objek siswa harus memahami materi sendiri tanpa penjelasan guru dan guru tidak akan repot-repot untuk menjelaskan semua yang ada dimateri. pendekatan saintifik dikatakan dapat memberikan suatu pemahaman kepada siswa tersebut dalam mengenal suatu informasi dan memahami berbagai materi yang menggunakan pendekatan ilmiah, informasi tersebut bisa berasal dari mana saja, kapan saja dan tidak bergantung pada informasi yang searah dari guru. Penerapan pendekatan saintifik dalam pembelajaran akan melibatkan suatu keterampilan yang terdapat pada suatu proses seperti mengamati, menanya, mencoba, menalar, dan mengkomunikasikan. (Hosnan dalam Mega Selvira Paut,2016)

Pendekatan Saintifik adalah pendekatan yang memberikan pemahamahan kepada siswa tentang pendekatan menggunakan langkah-langkah serta kaidah ilmiah dalam proses belajar mengajar. Langkah ilmiah yang diterapkan adalah menemukan suatu masalah, merumuskan masalah, mengajukan hipotesis, mengumpulkan data, menarik kesimpulan (Daryanto.2014) dalam proses belajar mengajar agar siswa mencari tahu berbagai sumber melalui mengamati, menanya, mencoba, mengolah, menyajikan, menyimpulkan pembelajar atau pendekatan saintifik memiliki 4 karakteristik 1) berpusat terhadap siswa 2) melibatkan keterampilan dan penugasan konsep 3) melibatkan proses kognitif yang potensi dalam perkembangan intelek, khususnya keterampilan berpikir yang pada siswa 4) mengembangkan karakter yang ada pada siswa (Hosnan \& sihombang, 2014) .

Lingkaran dapat diartikan sebagai suatu garis lengkung yang kedua ujungnya saling bertemu dan semua titik yang terletak di garis lengkung pada lingkaran akan mempunyai suatu jarak yang sama terhadap sebuah titik tertentu. Indikator pada dilingakaran dapat diuraikan dari materi lingkaran, yaitu: 1) dengan menemukan nilai phi, 2) menentukan rumus keliling dan luas pada lingkaran, dan 3)menghitung keliling, luas lingkaran. Lingkaran diartikan sebagai kurva tertutup sederhana yang memiliki arti tempat kedudukan titik-titik yang berjarak sama terhadap itik tertentu. Jarak yang sama disebut jari-jari lingkaran dan titik tersebut disebut pusat pada lingkaran

Berdasarkan Rumusan masalah diatas maka peneliti merasa tertarik untuk mengadakan penelitian Pengaruh Pendekatan Saintifik dalam proses belajar mengajar siswa kelas VIII SMP N 3 Kota bengkulu materi Lingkaran. Pendekatan saintifik merupakan pendekatan ilmiah dalam kukulum K13. Kemendikbud (2013) menyatakan proses pembelajaran saintifik diartikan sebagai suatu perpaduan antara proses pembelajaran yang sedang berlangsung terfokus pada suatu eksplorasi, elaborasi, dan konfirmasi, dan juga dilengkapi dengan mengamati, menanya dan mengkomunikasikan. Tujuan dari pembelajaran yang ada pada pembelajaran saintifik yaitu menekankan bahwa belajar tidak hanya terjadi diruang kelas saja, tetapi belajar juga bisa dilakukan dilingkungan sekolah dan masyarakat..pendekatan saintifik merupakan suatu proses pembelajaran yang dapat dirancang sedemikian rupa agar siswa secara aktif dapat mengkonstruk suatu konsep dan prinsip melalui tahap mengamati (untuk mengidentifikasi dan menemukan masalah), merumuskan sebuah masalah, mengajukan dan merumuskan hipotesis. Mengumpulkan sebuah data kita dapat menggunakan berbagai teknik., menganalisis data-data, menarik sebuah kesimpulan beserta dapat mengkomunikasikan prinsip-prinsaip yang telah ditemukan. Pendekatan saintifik dapat memberikan sebuah pemahaman kepada siswa dalam 
mengenal dan memahami sebuah materi yang menggunakan pendekatan ilmiah. Sumber informasi tidak hanya didapat dari guru saja tetapi sumber informasi dapat diambil dari mana saja dan kapan saja.(Hosnan,2014:34)

Proses pembelajaran dengan pendekatan saintifik dapat dikatakan agar siswa mampu merumuskan sebuah masalah (dengan banyak bertanya), bukan hanya menyelesaikan masalah dengan menjawab saja tetapi siswa diwajibkan untuk bertanya. Proses pembelajaran dilakukan untuk melatih berpikir analistis (siswa diajarkan bagaimana mengambil sebuah keputusan) bukan hanya berpikir mekanisti rutin saja dengan mendengarkan dan menghapal sesaat. (Majid, 2014: 194). Pendekatan saintifik dapat dikatakan sebagai upaya untuk mengembangkan kemampuan peserta didik untuk berpikir kreatif dan belajar secara mandiri. Guru dianjurkan untuk menetapkan pembelajaran k13 seorang guru harus melakukan k13 dengan kokponenkomponen pendekatan saintifik. (Ridwan, 2014:VII)

Nurul (johari dkk, 2014:12) Pembelajaran berpendekatan saintifik adalah pembelajaran yang berperan secara langsung, baik secara individu maupun secara bersamaan (kelompok) dengan menggunakan pendekatan ilmiah. Pendekatan saintifik adalah pendekatan dalam pembelajaran yang menggunakan ;langkah-langkah yang mengandung kaidah pada proses pembelajaran berlangsung.(Musifiqon dan nurdiansyah,2015) Pendekatan saintifik yang dilakukan secara langsung disetiap sekolah akan menghasilkan hasil yang tidak sama dengan aspek yang berbeda. Hal ini terjadi dengan tingkat pemahaman guru yang berbeda ketika guru menerapkan pembelajaran menggunakan pendekatan saintifik (Rustam, 2017) .

Yani (2013:125) Menyatakan bahwa dalam pembelajaran pendekatan saintifik ada 5 langkah yang akan digunakan. Mengamati,Menanya, mencoba, menalar, Memgasosiasikan dan mengkomunikasikan. Dalam langkah-langkah tersebut pembelajaran pendekatan saintifik siswa dia ajak untuk melakukan proses pencarian pengetahuan dengan melakukan tahap-tahap tersebut. Depdiknas (2013) penggunaan pendekatan saintifik dalam pembelajaran bertujuan untuk mencapai suatu kompetensi, setelah pembelajaran berlangsung rasa ingin tahu siswa meningkat, siswa berani dalam mengajukan pertanyaan, siswa dapat belajar secara mandiri tanpa bimbingan guru. Pendekatan saintifik pendekatan yang menggunakan proses ilmiah yang dilakukan melalui kegiatan, mengamati, menanya, mencoba, menalar dan mengkomunikasikan yang terdapat didalam kegiatan kreativitas dan temuan-temuan siswa merupakan pendekatan dalam saintifik. (Kosakasih, 2017:72) Pendekatan saintifik adalah pembelajaran yang dilakukan secara berkelompok yang memberikan suatu pengalaman kepada siswa secara langsung melaluih sebuah observasi sehingga siswa dapat mencari informasi sendiri dari sumber lain (Imran,2014).

Cohen (2007:15-16) menyatakan pendekatan saintifik adalah suatu pendekatan dimana di dalamnya harus membuat kejadian yang terjadi didalam kehidupan sehari-hari hal tersebut disebutkan dalam kehidupan sehari-hari. "As cuffandpayne (1979) say "A scientifik capproach neces saril yinvolves standars and dures for demon stratting the "empiricia lwarrant" Ofit'sfindings, shoping thematch orang fit betweenit'ss tatements and whatis happening orang has happened in theworld". Yang berarti, pendekatan ilmiah harus melibatkan standar dan prosedur untuk menunjukan 'bukti empiris' tuanya, menunjukan pertandingan atau kesesuaian antara pernyataan dan apa yang terjadi atau telah terjadi didunia. Dalam pelaksanaan model pembelajaran menggunakan pendekatan saintifik berlandasan pada keilmuan yang menekankan pentingnya kerja sama antar siswa dalam melakukan sebuah aktivitas dalam pengumpulan data, melalui observasi, menanya, eksperimen mengolah data informasi beserta mengkomunikasikan. Selama pembelajaran berlangsung siswa diwajibkan untuk mencari informasi dari berbagai sumber siswa tidak diwajibkan terpaku dengan guru tetapi siswa dibebaskan mencari informasi dari mana saja (Sufairoh,2016).

Penggunaan model ilmiah (scientific approach) dilaksanakan pada kurikulum K13, dalam proses kegiatan pembelajaran meliputi mengali suatu informasi melalui sebuah pengamatan untuk bertanya, mencoba, kemudian mengolah data ,menyajikan data, menganalisis, 
menyimpulkan dan mencipta Agar siswa aktif dan hokum dalam pembelajaran berlangsung dengan 5 tahapan tersebut (Suhartati,2016). pembelajaran yang membimbing Pendekatan saintifik dalam pembelajaran disajikan sebagai berikut :

Tabel 1. Kegiatan pada Pembelajaran saintifik

\begin{tabular}{|c|c|c|}
\hline Kegiatan & Aktivitas Guru & Aktivitas Siswa \\
\hline Mengamati & $\begin{array}{l}\text { Guru memfasilitasi siswa untuk } \\
\text { melakukan sebuah pengamatan untuk } \\
\text { melatih siswa seperti memperhatikan } \\
\text { (melihat,membaca, mendengan) dari hal } \\
\text { yang penting pada suatu benda dan } \\
\text { objek }\end{array}$ & $\begin{array}{l}\text { Siswa Melihat, mengamati, } \\
\text { membaca, mendengar, } \\
\text { menyimak (tanpa dan dengan } \\
\text { alat) }\end{array}$ \\
\hline Menanya & $\begin{array}{l}\text { Guru membimbing siswa untuk } \\
\text { mengajukan pertanyaan-pertanyaan } \\
\text { tentang hasil pengamatan objek yang } \\
\text { konkret sampai abstract. } \\
\text { Guru memberi kesempatan siswa untuk } \\
\text { siswa bertanya mengenai apa yang } \\
\text { dilihat }\end{array}$ & $\begin{array}{l}\text { Siswa bertanya kepada guru } \\
\text { tentang hasil pengamatan } \\
\text { objek yang konkret sampai } \\
\text { abstract mengenai apa yang } \\
\text { telah dilihatnya }\end{array}$ \\
\hline $\begin{array}{l}\text { Mengumpulkan } \\
\text { informasi }\end{array}$ & $\begin{array}{l}\text { Guru menyuruh siswa untuk } \\
\text { mengumpulkan, mencari informasi, } \\
\begin{array}{l}\text { membaca dari informasi berbagai } \\
\text { sumber }\end{array}\end{array}$ & $\begin{array}{l}\text { Siswa mencari, membaca dan } \\
\text { mengumpulkan informasi dari } \\
\text { berbagai sumber }\end{array}$ \\
\hline Mengolah data & $\begin{array}{l}\text { Guru dapat membimbing siswa untuk } \\
\text { dapat menarik kesimpulan hasil dari } \\
\text { mengola data. }\end{array}$ & $\begin{array}{l}\text { Siswa mengola data yg telah } \\
\text { dikumpulkan kemudian siswa } \\
\text { mengumpulkan hasil dari } \\
\text { kegiatan mengamati dan } \\
\text { kegiatan informasi. }\end{array}$ \\
\hline $\begin{array}{l}\text { Menarik } \\
\text { kesimpulan }\end{array}$ & $\begin{array}{l}\text { Guru dapat menarik kesimpulan materi } \\
\text { pembelajaran telah dibahas secara } \\
\text { singkat. }\end{array}$ & \begin{tabular}{lr} 
Siswa & \multicolumn{2}{r}{ menyimpulkan } \\
informasi dari & kegiatan \\
mengolah data. & \\
\end{tabular} \\
\hline $\begin{array}{l}\text { Mengkomunika } \\
\text { sihkan }\end{array}$ & $\begin{array}{l}\text { Guru memberi kesempatan kepada } \\
\text { siswa-siswanya } \\
\text { mengkomunikasihkan apa yang telah } \\
\text { dipelajari kegiatan tersebut dapat } \\
\text { dilakukan oleh siswa melalui } \\
\text { menceritakan apa yang ditemukan } \\
\text { dalam kegiatan mecari informasi, } \\
\text { mengasosiasikan dan menemukan pola. }\end{array}$ & $\begin{array}{l}\text { Siswa menceritakan kembali } \\
\text { apa yang ditemukan dalam } \\
\text { kegiatan mencari informasi, } \\
\text { mengasosiasikan dan } \\
\text { menemukan pola }\end{array}$ \\
\hline
\end{tabular}

\section{METODE PENELITIAN}

Penelitian ini merupakan penelitian kuantitatif. Penelitian ini adalah peneltian yang berlandaskan pada filsafat positivisme, digunakan untuk meneliti pada populasi atau sampel tertentu, pengumpulan data menggunakan instrument penenlitian, analisis data bersifat kuantitatif untuk menguji hipotesis yang telah ditetapkan. Penelitian ini dilaksanakan pada tahun ajaran 2020. Pembelajaran tersebut dilakukan saat tatap muka, tetapi berhubung kondisi dunia yang kurang memadai yaitu karena adanya wabah Covid 19 jadi penelitian ini dilanjutan dengan uji tes secara daring (online) dengan siswa melakukan tes soal, dengan mengambil jumlah siswa yang terbatas. Populasi pada penelitian ini seluruh siswa kelas VIII SMP Negeri 03 Kota bengkulu. Pengambilan sampel pada penelitian ini dilakukan secara purpove sampling karena tidak semua sampel memiliki kriteria yang sesuai dengan fenomena yang diteliti, yaitu 
dengan desain pertimbangan mengambil dua kelas yang relatif sama. Dengan siswa mendapatkan materi berdasarkan kurikulum yang sama, kedua sampel dalam satu kelas yang sama, guru menggunakan metode yang sama, karateristik pembelajaran serta kemampuan awal siswa sebanding. Populasi pada penelitian ini siswa kelas VIII di SMP 3 Kota Bengkulu Berjumlah 16 orang dengan 2 kelas yang diambil, yaitu Kelas VIII. A berjumlah 8 siswa dan VIII. B berjumlah 8 siswa. Diambil sebagai sampel untuk menentukan yang mana kelas eksperimen dan kelas kontrol yaitu dengan cara teknik random. Kelas VIII. A sebagai kelas eksperimen yaitu kelas yang diajar dengan cara berkelompok dengan menggunakan pendekatan saintifik dan VIII. B sebagai kontrol yang diajarkan dengan menggunakan pendekatan saintifik (tidak berkelompok). Penelitian ini merupakan penelitian eksperimen dengan menggunakan desain penelitian pottest only control Group Desain.

Tabel 2. pottest only control Group Desain.

\begin{tabular}{|c|c|c|}
\hline Kelas & Perlakuan & Potest \\
\hline Eksperimen & $\mathrm{X} 1$ & Y1 \\
\hline Kontrol & $\mathrm{X} 2$ & $\mathrm{Y} 2$ \\
\hline
\end{tabular}

Instrumen dalam penelitian ini menggunakan instrumen lembar observasi dan test soal. Instrumen dengan menggunakan lembar observasi yaitu untuk mengukur tingkat aktivitas guru dan siswa dalam proses pembelajaran dengan menggunakan pendekatan saintifik. Sedangkan instrumen tes soal digunakan untuk mengukur proses belajar mengajar kelas VIII pada materi lingkaran dalam bentuk tes soal essay sebanyak 4 soal pada materi lingkaran, sebelum diuji cobakan instrumen tersebut dianalisis kemudian setelaah selesai dianalaisis instrument tersebut diuji cobakan untuk mengetahui validitas dan rehabilitasnya. Untuk mengenai uji test, soal tersebut dianalisis validitas dan rehabilitas setelah dianalisis semua soal tersebut di uji cobakan dengan siswa. Instrumen valid adalah instrument yang memiliki validitas tinggi, sebaliknya instrument tidak valid adalah instumen yang validitasnya rendah. Maka dari itu dilakukanlah uji validitas pada setiap soal untuk mengetahaui instrument valid. Realibilitas adalah sesuatu instrumen yang dapat dipercaya sebagai alat pengumpulan data karena instrumen tersebut sudah baik, apabila instrumen yang digunakan berapa kali untuk mengukur objek yang sama akan menghasilkan data yang sama (Sugiyono,2010) dalam penelitian ini untuk melakukan perhitungan digunakan rumus alpha. Sesudah pemberian uji tes kepada siswa, kemudian diperlakukanlah kelas eksperimen yang diajar kelas menggunakan pendekatan saintifik yang berkaitan dengan kelas kontrol yang tidak menggunakan pendekatan saintifik.

Pada penelitian ini penelitian ini menggunakan dua teknik analisis data yaitu analisis deskriptif dan inferensial. Untuk mengetahui Pengaruh proses belajar siswa menggunakan pejmbelajaran dengan pendekatan saintifik tidak berkelompok menggunakan teknik analisis data deskriptif. Untuk mengetahui hipotesis proses belajar mengajar siswa sesudah dan sebelum menggunakan pendekatan saintifik dengan cara berkelompok atau tidak berkelompok menggunakan analisis data inferensial. Untuk mengetahui sebuah populasi yang berdistribusi normal atau tidak normal, yang menentukan mean data terbesar, data terkecil, rata-rata, median, modus, varians standar deviasi dan Skewnes dilakukan uji normalitas, uji normalitas akan dilaksanakan untuk data post-test untuk kelas eksperimen dan kelas kontrol. Untuk mengetahui apakah kelas yang diajar menggunakan kelas kontrol atau eksperimen atau kelas yang menggunakan pembelajaran saintifik berkelompok dan tidak berkelompok makan dilakukan uji homogonitas.

\section{HASIL DAN PEMBAHASAN}

Data kuantitatif yang diperoleh dari hasil test belajar mengajar siswa kelas VIII SMPN 03 Kota Bengkulu. Tes dilakukan pada materi lingkaran yang dilakukan secara Daring (online) kepada 16 siswa. Siswa tersebut diajarkan secara tatap muka dengan menggunakan metode pendekatan saintinfik secara berkelompok dan tidak berkelompok. Dengan adanya pandemi 
covid-19 peneliti mengambil subjek penelitian yang terbatas yaitu siswa yang terdiri dari 8 siswa di kelas kontrol dan 8 siswa di kelas eksperimen. Hasil tes dipaparkan pada tabel 3 berikut:

Tabel 3. Hasil Kelas Eksperimen dan Kontrol

\begin{tabular}{|c|c|c|}
\hline NO & EKSPERIMEN & KONTROL \\
\hline 1 & 50 & 25 \\
\hline 2 & 65 & 80 \\
\hline 3 & 45 & 25 \\
\hline 4 & 100 & 63 \\
\hline 5 & 30 & 65 \\
\hline 6 & 40 & 50 \\
\hline 7 & 30 & 45 \\
\hline 8 & 65 & 55 \\
\hline
\end{tabular}

Pada tabel diatas dijelaskan bahwa nilai maksimum kelas eksperimen adalah 100 dan nilai minimum adalah 30 , sedangkan pada kelas kontrol nilai maksimum 80 dan minimum 25 . Pada penelitian ini siswa diberikan soal uraian sebanyak 4 soal dengan materi lingkaran dikelas VIII. Soal tersebut diujikan oleh siswa untuk mengetahui perbedaan siswa pada saat proses belajar yang telah diajarkan oleh guru. Dengan menggunakan pembelajaran berkelompok dan yang tidak berkelompok secara online melalui group Whatshapp, sehingga kita dapat mengetahui bahwa pembelajaran yang cocok digunakan oleh siswa. Dibawah ini Peneliti telah melakukan hasil yang telah dianalisis dengan perlakukan siswa yaitu sebagai berikut :

Mann-Whitney Test

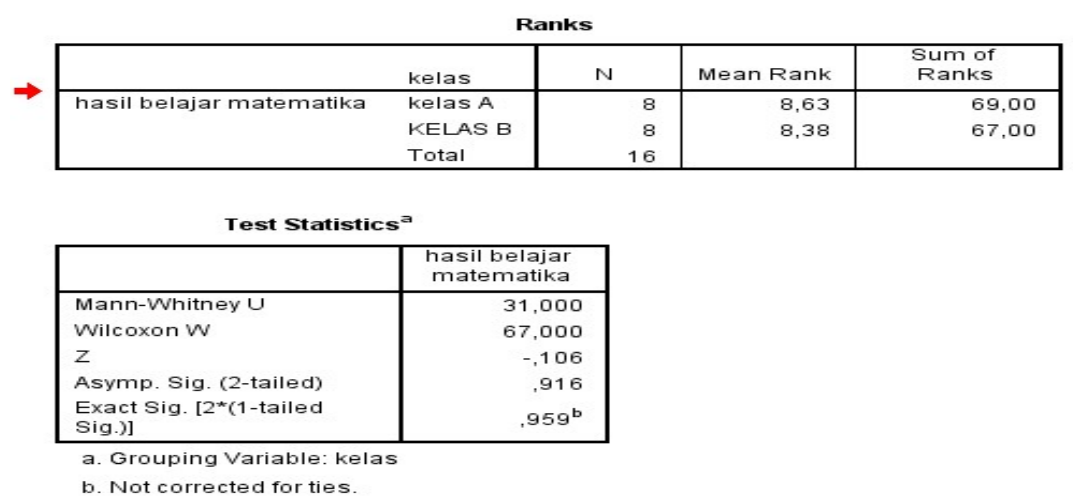

Gambar 2. Hasil analisis Mann-Whitney

Berdasarkan hasil data diatas yang menggunakan uji non parametris Mann Whitney Test didapatkan bahwa hasil belajar matematika pada kelas A lebih besar dengan angka mean Rank 8,63 Sedangkan pada kelas B dengan angka mean Rank 8,38. Berdasarkan output Test statistics diketahui bahwa nilai Asymp Sig.(2.talled) sebesar 0,916 $<0,05$ Hipotesis diterima, maka dapat dikatakan bahwa adanya perbedaan dari hasil yang signifikan antara kelas A dan kelas B dengan pengaruh pembelajaran kelas eksperimen dan kelas kontrol. Berikut adalah jawaban dari beberapa siswa yang telah dilampirkan oleh peneliti. 


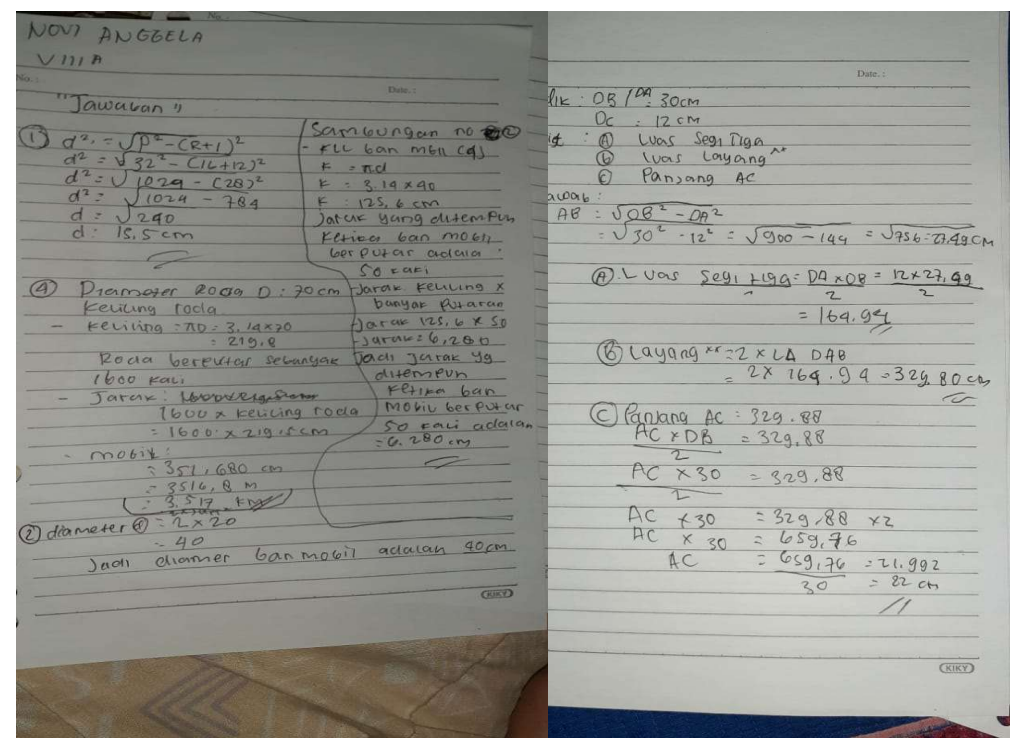

Gambar 3. Jawaban siswa 1
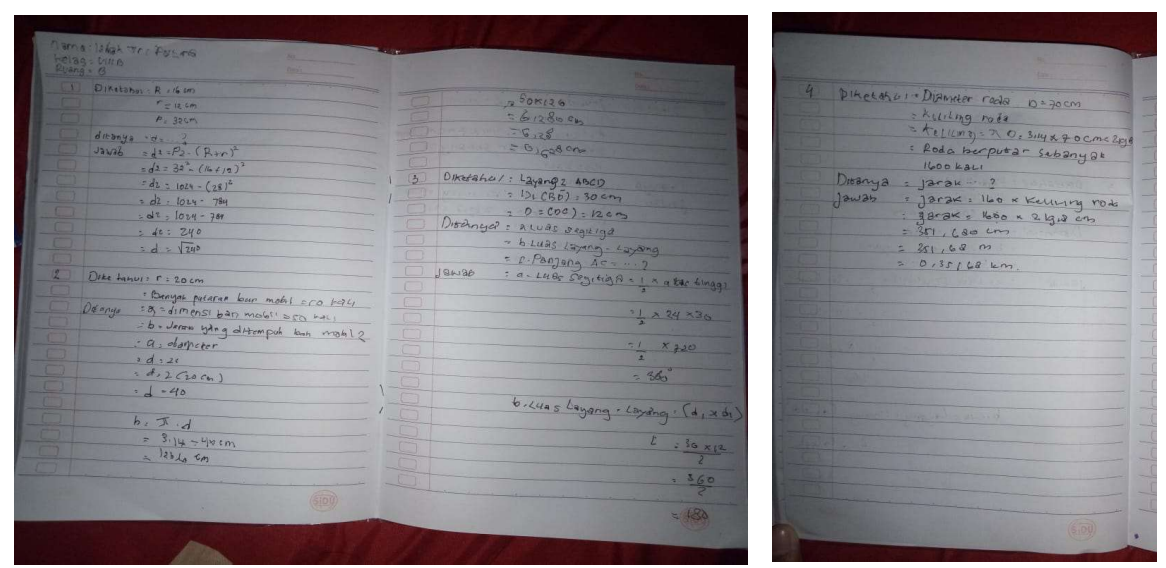

Gambar 4. Jawaban siswa 2

Dari hasil jawaban siswa 1 diatas dapat dilihat bahwa siswa dapat menyelesaikan masalah soal secara konsep dengan benar, akan tetapi kesalahan terletak pada operasi perhitungan dalam soal yang terletak pada no 3 . Dan hasil jawaban siswa 2 dapat dilihat bahwa siswa kurang dapat menyelesaikan masalah soal secara konsep dengan benar, akan tetapi kesalahan terletak pada operasi perhitungan dalam soal yang terletak pada no 3 dan 4 .

\section{KESIMPULAN DAN SARAN}

Berdasarkan penelitian diatas dapat disimpulkan bahwa penelitian ini dilakukan disaat dunia kurang membaik yaitu adanya Covid 19 sehingga penelitian ini dilakukan secara daring (Online) dengan siswa yang terbatas dengan jumblah 16 siswa yang terbagi 8 siswa untuk kelas eksperimen dan 8 siswa kelas control. Berdasarkan analisis yang didapat bahwa penggunaan pembelajaran saintifik untuk siswa lebih baik dengan Sig 0,916<0,05 maka dapat disimpulkan bahwa Hipotesis diterima dengan demikian dapat dikatakan bahwa ada perbedaan hasil antara kelas A dan kelas B.karena ada perbedaan yang signifikan maka dapat dikatakan bahwa ada pengaruh pembelajaran berkelompok dan tidak berkelompok. 


\section{DAFTAR PUSTAKA}

Carin \& Sund. (1975). Pengaruh Pendekatan Saintifik Pada Pembelajaran Matematika Terhadap Kemampuan Pemecahan Masalah dan Kemampuan Berpikir Tingkat Tinggi Siswa Kelas X IPA SMA Negeri 1 Kepahiang. Jurnal Pendidikan Raflesia,7(7),1-22.

Purwanto. (2002) . Peran Berpikir Kreatif dalam Proses Pembelajaran. Jurnal Formatif,2(3), 248-262.

Russefefendi. (2006) . Pengaruh Pendekatan Saintifik Terhadap Pemahaman Konsep Siswa Pada Pembelajaran Matematika Dikelas VIII MTS Patra Mandiri Palembang. Jurnal Pendidikan Matematika.JPM RAFA,261-262.

Cohen .(2007). Efektivitas Gaya Mencatat Linear dan Non Linear Berseting Saintifik dalam Pembelajaran Matematika.Jurnal Nasional Pendidikan Matematika,1-11.

Sugiyono . (2010) . Statistika untuk Penelitian .Bandung:Alfabeta.

Kemendikbud. (2013). Pengaruh Pendekatan Saintifik Terhadap Kemampuan Pemahaman Matematika Siswa Kelas VIII SMP Negeri 9 Kendari Pada Materi Operasi Aljabar. Jurnal Pendidikan Matematika,153-166.

Dimyati, M. (2013). Belajar \& Pembelajaran. Jakarta: Rineka Cipta.

Kemendikbud. (2013). Penggunaan Pendekatan Pembelajaran Saintifik dalam Meningkatkan Hasil Belajar Matematika Dikelas VIII MTS Patra Mandiri Palembang. Jurnal Pendidikan Matematika, JPM RAFA,Vol.1, No.2.263.

Yani. (2013). Pengaruh Pendekatan Saintifik Terhadap Prestasi Belajar Matematika di Tinjau dari Keaktifan Siswa. Prosiding Seminar Nasional Etnomatnesia .816

Kosasin. (2014). Pengaruh Pendekatan Saintifik Berbasis Proyek terhadap Hasil Belajar Matematika Siswa Kelas IV SD. e-Journal PGSD Universitas Pendidikan Ganesha,110.

Majid. (2014). Penggunaan Pendekatan Pembelajaran Saintifik dalam Menggunakan Hasil Belajar Matematika. Jurnal Ilmiah Mandala education, 108-113.

Daryanto. (2014). Penggunaan Pendekatan Pembelajaran Saintifik dalam Meningkatkan Hasil Belajar Matematika. Jurnal Ilmiah Manda Education,109-110.

Daryanto, D. (2014). Pendekatan pembelajaran saintifik Kurikulum 2013. Yogyakarta: Gava Media.

Ridwan. (2014). Pengaruh Pendekatan Saintifik terhadap Hasil Belajar Pengetahuan MatematikaTema Cita-Citaka di Tinjau Pada Siswa Kelas IV SD Negeri 27 Pemecutan. e-Journal PGSD Universitas Pendidikan Ganesha,1-12.

Imran. (2014). Pengaruh Pendekatan Scientifik terhadap Kemampuan Penalaran dan Komunikasi Matematika. Jurnal Bina Gogik, (1)2.

Hosnan \& Sihombang. (2014). Pengaruh Pendekatan Pembeljaran Matematika Realistik dan Saintifik terhadap Prestasi Belajar, Kemampuan Penalaran Matematis dan Minat Belajar. Jurnal Riset Pendidikan Matematika. 4(1),1-10.

Nurul. (2014). Pengaruh Pendekatan Saintifik Terhadap Hasil Belajar Matematika. Jurnal Komunitas Bahasa, Vol. 6(1).44.

Lestari, I. (2015). Pengaruh waktu belajar dan minat belajar terhadap hasil belajar matematika. Formatif: Jurnal Ilmiah Pendidikan MIPA, 3(2).

Muhammad, M., \& Nurdyansyah, N. (2015). Pendekatan pembelajaran saintifik.

Suhartati. (2016). Penerapan Pendekatan Saintifik Pada Materi Relasi dan Fungsi Kelas X Mana Banda Aceh. Jurnal Parelang,56-63. 
Pengaruh Pendekatan Saintifik Dalam Proses Belajar Mengajar Siswa Kelas Viii Materi

Lingkaran

Maryani ${ }^{1}$, Herlina Effendi ${ }^{2}$, Henky Sabantaro ${ }^{3}$

Sufairoh. (2016) .Pengaruh Pendekatan Saintifik Terhadap Kemampuan Pemecahan Masalah Matematika Siswa Kelas VIII Semester Genap SMP Negeri 1 Bandar Lampung.Jurnal Ilmiah Pendidikan Matematika STKIP PGRI Bandar Lampung.3(3),1-9.

Paut, M. S. (2016). Penerapan pendekatan saintifik pada siswa kelas IV di SD Pujokusuman 1 Yogyakarta. BASIC EDUCATION, 5(6), 511-517.

Rustam. (2017). Pengaruh Pendekatan Saintifik Berbasis ASESMEN Projek Terhadap Hasil Belajar Matematika. Journal BE Education technology.vol 3(4)PP,269-277.

Yuda Banindra Chrisnaji.(2019).Pengaruh Pendekatan Saintifik terhadap Kemampuan Berpikir Kritis Mahasiswa Buana Matematika:Jurnal Ilmiah Matematika dan Pendidikan Matematika,31-33. 